\title{
Streptomyces Pimoensis sp. nov., Isolated From the Taklimakan Desert in Xinjiang, China
}

\section{Ping Zhang}

Tarim University

Xiaoxia Luo

Tarim University

Xinrong Luo

Tarim University

Zhanwen Liu

Tarim University

Zhanfeng Xia

Tarim University

Chuanxing Wan

Tarim University

Lili zhang ( $\sim$ zhang63lyly@sina.com )

Tarim University https://orcid.org/0000-0002-9103-1181

\section{Research Article}

Keywords: Streptomyces pimoensis sp. nov., Polyphasic taxonomy, Actinomycete

Posted Date: December 1st, 2021

DOI: https://doi.org/10.21203/rs.3.rs-1066882/v1

License: (c) (i) This work is licensed under a Creative Commons Attribution 4.0 International License.

Read Full License 


\section{Abstract}

A novel Streptomyces strain, designated TRM $75549^{\top}$, was separated from a sample of sand in Pimo, Taklimakan desert, Xinjiang, North-West China. Phylogenetic analyses of the 16S rRNA gene sequences placed strain TRM $75549^{\top}$ within the genus Streptomyces with the highest similarities to Streptomyces flavoviridis NBRC $12772^{\top}$ (98.76\%). The whole-genome average nucleotide identity (ANI) value between strain TRM $75549^{\top}$ and S. flavoviridis NBRC $12772^{\top}$ is $88.20 \%$. Digital DNA-DNA hybridization (dDDH) value between strain TRM75549 ${ }^{\top}$ and S. flavoviridis NBRC $12772^{\top}$ is $44.10 \%$. They are well below the recommended $95-96 \%$ and $70 \%$ cut-off points for designated species respectively. A multi-locus sequence analysis of five house-keeping genes ( $a t p D, g y r B, \operatorname{rec} A, r p o B$ and $\operatorname{trp} B$ ) and phylogenomic analysis also illustrated that strain TRM75549 ${ }^{\top}$ should be assigned to the genus Streptomyces. Strain TRM75549 contained MK-9 $\left(\mathrm{H}_{6}\right)$ and MK-9 $\left(\mathrm{H}_{8}\right)$ as predominant menaquinones. The diagnostic diamino acid of cell walls was identified as LL-diaminopimelic acid and Meso-diaminopimelic. The whole-cell sugar pattern of strain TRM $75549^{\top}$ consisted of mannose and glucose. The major fatty acids $(>5 \%)$ were iso- $\mathrm{C}_{14: 0}$, iso$\mathrm{C}_{15: 0}$, anteiso- $\mathrm{C}_{15: 0}$, iso- $\mathrm{C}_{16: 1} \mathrm{H}$, iso- $\mathrm{C}_{16: 0}$. The polar lipids were diphosphatidylglycerol, lysophosphatidylglycerol, phosphatidylethanolamine, phospholipids, phosphatidylglycerol, phosphatidylinositol, phosphatiylinositol mannosides and unidentified phospholipids. Strain TRM75549 ${ }^{\top}$ could be differentiated from S. flavoviridis NBRC $12772^{\top}$, based on physiological and biochemical characteristics. Based on the data from this polyphasic study presented above, strain TRM $75549^{\top}$ is represent ative of a novel species of the genus Streptomyces, for which the name Streptomyces pimoensis sp. nov. is proposed. The type strain is $\operatorname{TRM} 75549^{\top}\left(=\mathrm{CCTCC} A \mathrm{~A} 2020054^{\top}=\mathrm{LMG} 32221^{\top}\right)$.

\section{Introduction}

The genus Streptomyces was first proposed by WaKsman and Henrici (1943). Streptomyces species are aerobic actinomycetes with a GC-rich genome, most of which can form broadly branched matrix mycelia and aerial mycelia, which usually differentiate into spore chains (Gadagkar and Kumar 2005). Many members of the genus Streptomyces are known to produce a variety of biologically active metabolites, including antibiotics, enzymes, enzyme inhibitors, vitamins, etc. (Liu et al. 2018).

In recent years, as domestic and foreign scholars have continuously explored the active products of Streptomyces, the research of new species of Streptomyces has gradually become a new direction. The isolation sources of new species of Streptomyces also include various special environments such as oceans, deserts, and animal and plant bodies.

In this article, the strain TRM $75549^{\top}$ was separated from a sample of sand in Pimo, Taklimakan desert, Xinjiang, North-West China. It has good antibacterial activity against the three pathogenic bacteria grampositive bacteria Staphylococcus aureus ATCC25923, Enterococcus faecalis ATCC29212 and gramnegative bacteria Escherichia coli ATCC25922. Therefore, this strain was selected for heterogeneous classification and identification. In the present study, the taxonomic status of strain TRM $75549^{\top}$ was 
determined using a polyphasic approach. The resultant data showed that TRM $75549^{\top}$ represents a novel Streptomyces species for which the name Streptomyces pimoensis is proposed.

\section{Materials And Methods}

\section{Strain isolation and culturing}

The strain TRM $75549^{\top}$ was isolated by standard dilution plate method by growth on Gauze's No. 1 medium (g/L): soluble starch $20 \mathrm{~g}, \mathrm{KNO}_{3} 1 \mathrm{~g}, \mathrm{~K}_{2} \mathrm{HPO}_{4} 0.5 \mathrm{~g}, \mathrm{MgSO}_{4} \cdot 7 \mathrm{H}_{2} \mathrm{O} 0.5 \mathrm{~g}, \mathrm{NaCl} 20 \mathrm{~g}, \mathrm{FeSO}_{4} \cdot 7 \mathrm{H}_{2} \mathrm{O}$ $0.01 \mathrm{~g}$, Agar $16 \mathrm{~g}, \mathrm{pH} 7.0-7.6$. (Guan et al. 2010), incubated at $30{ }^{\circ} \mathrm{C}$ for 10 days, and was preserved in $20 \%$ (V/V) glycerol at $-20{ }^{\circ} \mathrm{C}$ and lyophilized in $20 \%$ skim milk powder. Biomass for chemical and molecular research was obtained by cultured the strain in trypsin soy broth for 14 days on oscillators at $180 \mathrm{rpm}$ and $30^{\circ} \mathrm{C}$. The closely related type strains Streptomyces flavoviridis DSM 40153 was purchased from Deutsche Sammlung von Mikroorganismen und Zellkulturen (DSMZ) and was cultivated under comparable conditions as reference strain.

\section{Morphological, cultural, physiological, and biochemical characteristic}

The cultural characteristics of strain TRM75549 ${ }^{\top}$ were determined on ISP media (ISP1, ISP2, ISP3, ISP4, ISP5, ISP6 and ISP7)(Shirling EB, Gottlieb D 1966), Czapek's agar, Potato dextrose agar, Gauze's No. 1 medium and Nutrient agar (Waksman 1967) for 14 days at $30^{\circ} \mathrm{C}$. Morphology of mycelia and spores of strain TRM $75549^{\top}$ were observed by optical microscopy and scanning electron microscopy as described by Williams and Davies(1967) after 10 daysof incubation at $30^{\circ} \mathrm{C}$ on Gauze's No. 1 medium.

Different temperatures $(4,10,15,28,30,37,40,45,50$ and 55 degrees $\mathrm{C}), \mathrm{pH}(\mathrm{pH} 4.0-12.0$, interval $1.0 \mathrm{pH}$ unit) (Xu et al., 2005) and $\mathrm{NaCl}$ concentrations as described in Goodfellow (1986), measured $0-10 \%$ on Gauze's No. 1 medium at intervals of 1\%,w/v). Physiological characteristics and utilization of carbon sources were assessed following Williams et al. (1989). The uses of liquefaction of gelatin, milk peptonization and solidification, urea, starch hydrolysis, nitrate reduction, melanin production and production of $\mathrm{H}_{2} \mathrm{~S}$ were studied(Gordon 1974; Yokota et al. 1993).

\section{Antibacterial and antifungal activity}

The antimicrobial efficacy of these isolates was tested been tested against various organisms S.aureus ATCC25923, E. faecalis ATCC29212, E.coli ATCC25922 using Kirby-Baur agar diffusion method (Maiti et al. 2020). In brief, lawns of test organisms were prepared on agar medium and 14-days-old colonies were placed on the lawn. The plates were kept at $4^{\circ} \mathrm{C}$ for $2 \mathrm{~h}$ for a homogenous distribution of antimicrobial compound before the growth of test organisms followed by the incubation at $37^{\circ} \mathrm{C}$ for $24 \mathrm{~h}$. After incubation, the zone of inhibitions around the colony was observed and measured.

\section{Chemotaxonomy}


The cells collected by centrifugation were washed with distilled water, and then freeze-dried. The method proposed by Staneck and Roberts was used to determine cell wall amino acids( Staneck and Roberts 1974). Use the method proposed by Tang et al. to analyze whole cell sugars. (2009). Polar lipids were extracted and separated by two-dimensional TLC and identified by the method proposed by Minnikin et al. (1984). Menaquinones were extracted from freeze-dried biomass according to the method proposed by Collins et al. (1977), and subjected to HPLC analysis (Wang et al. 2011). According to the method proposed by Sasser (1990), cellular fatty acids were extracted from fresh cells, and GS chromatographic analysis was performed.

\section{Genome sequencing and phylogenetic analysis}

The method of Chun and Goodfellow (1995) was used to extract genomic DNA and PCR amplification of 16S rRNA gene sequence. EzBioCloud (https://www.ezbiocloud.net/identify, Yoon et al. 2017) calculated the similarity of the 16S rRNA gene sequence with other strains, and then the sequence of the strains with a close relationship were selected to construct the phylogenetic tree. These sequences were aligned using MEGA 7.0 software (Kumar et al., 2016) with Neighbor-Joining (Saitou 1987), Maximum likelihood (Felsenstein 1981), and Maximum-Parsimony (Fitch 1971) methods to construct phylogenetic trees. The topologies of the phylogenetic trees were evaluated by the bootstrap resampling method with 1000 replicates (Felsenstein 1985). A complete genome sequence of strain was obtained using an Illumina platform and assemble by Velvet 1.2.10. The $\mathrm{G}+\mathrm{C}$ content of genomic DNA was determined from the whole genome sequence by Average Nucleotide Identity (ANI) calculator (http://www.ezbiocloud.net/tools/ani). The digital DNA-DNA hybridization (dDDH) values were calculated on the GGDC website using formula 2(http://ggdc.dsmz.de/ggdc.php), originally described by Auch et al (2010) and updated by Meier-Kolthoff et al (2013). The genome sequences of strain TRM75549 ${ }^{\top}$ (accession no. JAHWZY000000000) and strain S. flavoviridis NBRC $12772^{\top}$ (accession no. BMTE00000000) have been submitted to GenBank. Housekeeping genes used for multilocus sequence analysis (MLSA), as used in previous Streptomyces analysis, were atpD (ATP synthase subunit D), gyrB (DNA gyrase $B$ subunit), recA (recombinase A), rpoB (RNA polymerase beta subunit) and trpB (tryptophane $B$, beta subunit). Each locus for each strain was concatenated head to tail in frame as follows: atpD, gyrB, recA, ropB and trpB. The sequences for all loci of other related strains were obtained from the NCBI (https://www.ncbi.nlm.nih.gov/).

\section{Results And Discussion}

After the strain TRM $75549^{\top}$ was cultured at $30^{\circ} \mathrm{C}$ for 7 days, it was grown on 11 standard media, and the colors of aerial mycelia and substrate mycelia were recorded (Table 1). The strain was observed to grow well on ISP 1, ISP 4, ISP 5, ISP 7, Gauze's No. 1 agar, moderately well on ISP 2, Czapek's agar, Patato dextrose agar, with slow growth on ISP 3 and ISP 6, and none on nutrient agar. The results of the antibacterial experiment showed that TRM75549 ${ }^{\top}$ inhibits $E$. coli with an average diameter of $2 \mathrm{~cm}$, inhibits $E$. faecalis with an average diameter of $1.5 \mathrm{~cm}$, and inhibits $S$. aureus with an average diameter of 
$1.3 \mathrm{~cm}$; Streptomyces flavoviridis DSM $40153^{\top}$ inhibits E.coli with an average diameter of $1.1 \mathrm{~cm}$, and inhibits $E$. faecalis, with an average diameter of $1.3 \mathrm{~cm}$, but $S$.aureus has no obvious transparent circle (Supplementary Fig. S1). Strain TRM $75549^{\top}$ could be distinguished from S. flavoviridis DSM $40153^{\top}$ by some phenotypic characteristics, inparticular cultural characteristics (Supplementary Table S1).

Morphological characteristics of strain TRM $75549^{\top}$ were observed using SEM (Fig. 1). The strain was observed to form an abundant white aerial mycelium, occasionally twisted, which differentiates into spore chains. Each spore was observed to be olivary with a hairy surface. Strains grow at $15-45^{\circ} \mathrm{C}, \mathrm{pH} 6.0-$ 9.0 and $0-9 \% \mathrm{NaCl}$, and are best grown at $30^{\circ} \mathrm{C}$ and $\mathrm{pH} 7.0$ at $1 \%(\mathrm{w} / \mathrm{v}) \mathrm{NaCl}$. The strains of hydrogen peroxide enzymes, amyloid hydrolysis, nitrate reduction, cellulose decomposition were all positive, while urease, gelatin liquefaction, milk peptonization and solidification, oxidase, melanin production, hydrogen sulfide production were negative. The strain could degrade Tweens $20,40,60$ and 80 .

Table 1

Characteristics of strain TRM $75549^{\top}$ grown on various media at $30{ }^{\circ} \mathrm{C}$ for 14 days

\begin{tabular}{|llll|}
\hline Medium & Growth & Colour of mycelia \\
\hline ISP 1 & & Aerial & Substrate \\
\hline ISP 2 & Good & Grayish white & Pale yellow \\
\hline ISP 3 & Moderate & Grayish white & white \\
\hline ISP 4 & Poor & pale green & kelly green \\
\hline ISP 5 & Good & Grayish white & Pale yellow \\
\hline ISP 6 & Good & Yellowish white & kelly green \\
\hline ISP 7 & Poor & Grayish white & Greyish yellow \\
\hline Gauze's No. 1 agar & Good & Grayish white & kelly green \\
\hline Czapek's agar & Moderate & Grayish white & white \\
\hline Patato dextrose agar & Moderate & Grayish white & white \\
\hline nutrient agar & None & None & None \\
\hline
\end{tabular}

The cell wall of strain TRM75549 ${ }^{\top}$ contained LL-diaminopimelic acid and Meso-diaminopimelic, and the whole cell hydrolyzed sugar type was mannose and glucose. The polar lipids were diphosphatidylglyceroln (DPG), lysophosphatidylglycerol (LPG), phosphatidylethanolamine (PE), phospholipids (PLS), phosphatidylglycerol (PG), phosphatidylinositol (PI), phosphatidylinositol mannosides (PIM) and an unidentified phospholipid (Supplementary Fig.S2). The predominant 
menaquinones were MK-9 $\left(\mathrm{H}_{6}\right)$ and MK-9 $\left(\mathrm{H}_{8}\right)$. The major fatty acids $(>5 \%)$ were iso- $\mathrm{C}_{14: 0}(10.64 \%)$, iso$\mathrm{C}_{15: 0}(5.01 \%)$, anteiso- $\mathrm{C}_{15: 0}(11.98 \%)$, iso- $\mathrm{C}_{16: 1} \mathrm{H}(12.87 \%)$, iso- $\mathrm{C}_{16: 0}(33.46 \%)$.

The GenBank login number of the $16 \mathrm{~S}$ rRNA gene sequence of the strain TRM75549 ${ }^{\top}$ is MW479154, and the closest phylogenetic neighbor was S. flavoviridis NBRC $12772^{\top}$ (GenBank accession no. AB184842). The average nucleotide identity value and the digital DNA-DNA hybridization value between strain TRM $75549^{\top}$ and S. flavoviridis NBRC $12772^{\top}$ were $88.20 \%$ and $44.10 \%$, respectively, well below $95-96 \%$ and $70 \%$ cut-off point recommended for delineating species. The phylogenetic tree constructed from the $16 \mathrm{~S}$ rRNA gene sequence through the Neighbor-Joining method showed that the strain TRM75549 ${ }^{\top}$ formed a unique clade (Fig. 2), which was also restored in the Maximum-Likelihood trees and MaximumParsimony trees (Supplementary Fig. S3, S4). The MLSA with the concatenated atpD, gyrB, recA, rpoB and $\operatorname{trp} B$ genes showed that the strain is clustered with S. flavoviridis NBRC $12772^{\top}$, and the MLSA distances were much greater than the generally accepted threshold value of 0.007 for species delineation (Fig. 3 ). The $\mathrm{G}+\mathrm{C}$ content in the draft genome sequence of strain TRM $75549^{\top}$ was identified as $72.14 \mathrm{~mol} \%$. All the data suggested that strain TRM $75549^{\top}$ was a member of the genus Streptomyces. However, on the basis of a combining compare of phylogenetic distinctness and differences in chemotaxonomic and physiological characteristics (Table 2), it is considered that strain TRM $75549^{\top}$ is the representative of a new species of Streptomyces, named Streptomyces Pimoensis sp. nov. is proposed. The type strain is TRM $75549^{\top}\left(=\right.$ CCTCC AA $2020054^{\top}=$ LMG $\left.32221^{\top}\right)$. 
Table 2

Biochemical characteristics of strain TRM $75549^{\top}$ compared to its phylogenetic relatives

\begin{tabular}{|c|c|c|}
\hline Characteristic & 1 & 2 \\
\hline Spore-chain morphology & Straight & Spirale \\
\hline Spore surface & Hairy & Spiny \\
\hline Optimum temperature & $30^{\circ} \mathrm{C}$ & $28^{\circ} \mathrm{C}$ \\
\hline $\mathrm{pH}$ tolerance & $6.0-9.0$ & $7.0-9.0$ \\
\hline $\mathrm{NaCl}$ tolerance $(\%, \mathrm{w} / \mathrm{v})$ & $0-9$ & $0-5$ \\
\hline Glucose & + & + \\
\hline $\mathrm{L}(+)$ Arabinose & + & + \\
\hline Cellobiose & + & + \\
\hline $\mathrm{D}(+)$ Fructose & + & + \\
\hline $\mathrm{D}(+)$ Galactose & + & + \\
\hline $\mathrm{D}(+)$ Maltose & + & + \\
\hline $\mathrm{D}(+)$ Mannitol & + & + \\
\hline Lactose & + & - \\
\hline Xylose & + & + \\
\hline Raffinose & - & - \\
\hline myo-Inositol & w & + \\
\hline Sucrose & w & - \\
\hline L-Rhamnose & - & + \\
\hline Gelatin liquefaction & + & w \\
\hline Starch hydrolysis & + & + \\
\hline Nitrate reductase & + & + \\
\hline Urea & - & - \\
\hline $\mathrm{H}_{2} \mathrm{~S}$ production & - & + \\
\hline Melanin production & - & - \\
\hline Milk peptonization & - & + \\
\hline Major whole-cell sugars & Glucose & Glucose \\
\hline
\end{tabular}




\begin{tabular}{|c|c|c|}
\hline & mannose & \\
\hline \multirow[t]{2}{*}{ Major cell-wall diamino acid } & LL-DAP & LL-DAP \\
\hline & meso-DAP & \\
\hline \multirow[t]{2}{*}{ Phospholipids } & DPG, PE, PI, PG, & DPG, PE, PC, PG, \\
\hline & PIM, PLS, LPG & NPG, PLS, LPG \\
\hline \multirow[t]{2}{*}{ Predominant menaquinones } & MK-9 $\left(\mathrm{H}_{6}\right)$, MK-9 $\left(\mathrm{H}_{8}\right)$ & MK-8,MK-8( $\left(\mathrm{H}_{2}\right)$ \\
\hline & & MK-8 $\left(\mathrm{H}_{6}\right), \mathrm{MK}-9\left(\mathrm{H}_{6}\right)$ \\
\hline \multirow{2}{*}{$\begin{array}{l}\text { Major cellularfatty acids } \\
(>10 \%)\end{array}$} & iso- $\mathrm{C}_{16: 0}$, iso- $\mathrm{C}_{16: 1}{ }^{\mathrm{H}}$, & iso- $\mathrm{C}_{16: 0}$, anteiso- $\mathrm{C}_{15: 0}$ \\
\hline & anteiso- $\mathrm{C}_{15: 0,}$, iso- $\mathrm{C}_{15: 0}$ & $C_{16: 0,}$ Sum 3 \\
\hline
\end{tabular}

Strains: 1, TRM75549' 2 , Streptomyces flavoviridis DSM 40153'; All data are from this study. + , Positive; w, weakly positive; -, negative.

Description of Streptomyces pimoensis sp. nov.

Streptomyces pimoensis (pi.mo.en'sis N.L.Masc. adj. pimoensis. Pertaining to Pimo, Taklimakan desert, Xinjiang, North-West China, from where the type strain was isolated).

This species is aerobic, Gram-positive actinomycetes. The aerial mycelium is densely straight or tortuous, and each spore was observed to be olivary with a hairy surface. Grow well on ISP 1, ISP 4, ISP 5, ISP 7 , Gauze's No. 1 agar, grow moderately on ISP 2, Czapek's agar, Patato dextrose agar. The strain can grow at $0-9 \%(\mathrm{w} / \mathrm{v}) \mathrm{NaCl}, \mathrm{pH} 6.0-9.0$ and $15-45^{\circ} \mathrm{C}$, with optimum growth at $1 \%(\mathrm{w} / \mathrm{v}) \mathrm{NaCl}, \mathrm{pH} 7.0-8.0$, and $30^{\circ} \mathrm{C}$ respectively. Glucose, arabinose, D-sorbitol, D-xylose, fructose, maltose, mannitol, lactose, Dgalactose, inositol, ribose, cellobiose are utilized. Sucrose, rhamnose, raffinose, trehalose are not utilized. Starch hydrolysis, nitrate reduction, cellulose decomposition, degradations of Tweens 20, 40, 60 and 80 are positive, whereas urease, gelatin liquefaction, milk peptonization and solidification, oxidase, melanin production, $\mathrm{H}_{2} \mathrm{~S}$ production are negative. The cell wall contains LL-diaminopimelic acid and mesodiaminopimelic. Whole cell hydrolysates contain mannose and glucose. The polar lipids were diphosphatidylglyceroln (DPG), lysophosphatidylglycerol (LPG), phosphatidylethanolamine (PE), phospholipids (PLS), phosphatidylglycerol (PG), phosphatidylinositol (PI), phosphatiylinositol mannosides (PIM) and an unidentified phospholipid. The menaquinone system contains MK-9 $\left(\mathrm{H}_{6}\right)$ and MK-9 $\left(\mathrm{H}_{8}\right)$. The major fatty acids are iso- $\mathrm{C}_{14: 0}(10.64 \%)$, iso- $\mathrm{C}_{15: 0}(5.01 \%)$, anteiso- $\mathrm{C}_{15: 0}(11.98 \%)$, iso$\mathrm{C}_{16: 1} \mathrm{H}(12.87 \%)$, iso- $\mathrm{C}_{16: 0}(33.46 \%)$.

The type strain is TRM75549 ${ }^{\top}\left(=C C T C C\right.$ AA $2020054^{\top}=L M G 32221^{\top}$ ), isolated from the Pimo, Taklimakan desert, Xinjiang, North-West China. The G+C content in the draft genome sequence of strain TRM75549 is $72.14 \mathrm{~mol} \%$. The GenBank/EMBL/DDBJ accession number for the genome and 16S rRNA gene sequence of strain TRM75549 ${ }^{\top}$ is JAHWZY000000000 and MW479154. 


\section{Declarations}

Acknowledgements

Thanks to Key Laboratory of Protection and Utilization of Biological Resources in Tarim Basin of Tarim Basin of Xinjiang Production \& Construction Corps for providing research facilities.

\section{Author contributions}

Ping Zhang participated in the experiment and preparation of the first draft. Xiaoxia Luo,Xinrong Luo,Zhanwen Liu, Zhanfeng Xia, and Chuanxing Wan gave guidance during the experiment. Lili Zhang contributed to reagents, instrumentation and the financial support for this work.

\section{Funding information}

The research was funded by Supported by Bingtuan Science and Technology Program (2017DB002) and the National Natural Science Foundation of China-Xinjiang Joint Fund Key Project (U1703236) , Microbial Resources Utilization Innovation Team in the Key Field of Xin Jiang Production and Construction Corps (2017СВ014).

\section{Compliance with ethical standards}

The authors state that there is no confict of interest.

\section{Ethical approval}

This article does not contain any research conducted by any author on human participants or animals.

\section{References}

1. Auch AF, von Jan M, Goker M et al (2010) Digital DNA-DNA hybridization for microbial species delineation by means of genome-to-genome sequence comparison. Stand Genom Sci 2:117-134

2. Chun JS, Goodfellow M (1995) A phylogenetic analysis of the genus Nocardia with 16S rRNA gene sequences. Int J Syst Bacteriol 45:240-245

3. Collins MD, Pirouz T, Goodfellow M, Minnikin DE (1977) Distribution of menaquinones in actinomycetes and corynebacteria. J Gen Microbiol 100:221-230

4. Felsenstein J (1981) Evolutionary trees from DNA sequences: a maximum likelihood approach. $J$ Mol Evol 17:368-376

5. Felsenstein J (1985) Confidence limits on phylogenies: an approach using the bootstrap. Evolution 39:783-789

6. Fitch WM (1971) Toward defining the course of evolution: minimum change for a specific tree topology. Sys Zool 20:406-416 
7. Gadagkar SR, Kumar S (2005) Maximum likelihood outperforms maximum parsimony even when evolutionary rates are heterotachous. Mol Biol Evol 22:2139-2141

8. Goodfellow M (1986) Genus Rhodococcus Zopf 1891, 28AL.In: Sneath PHA, Mair NS, Sharpe NE, Holt JG (eds) Bergey's anual of systematic bacteriology, vol 2. Williams \&Wilkins, Baltimore, pp 1472-1481

9. Gordon RA (1974) Nocardia coeliaca, Nocardia autotrophica, and the Nocardin strain. Int J Syst Bacteriol 24:54-63

10. Kelly KL (1964) Inter-Society Color Council-National Bureau of Standards Color Name Charts illustrated with centroid colors. Washington: US Government Printing Office

11. Kumar S, Stecher G, Tamura K (2016) MEGA7: molecular evolutionary genetics analysis version 7.0 for bigger datasets. Mol Biol Evol 33:1870-1874

12. Lee I, Kim YO, Park SC, Chun J (2015) Orthoani: an improved algorithm and software for calculating average nucleotide identity. Int J Syst Evol Microbiol 66:1100-1103

13. Liu R, Deng Z, Liu T (2018) Streptomyces species: Ideal chassis for natural product discovery and overproduction. MetabEng 50:74-84

14. Maiti PK, Das S, Sahoo P, Mandal S (2020) Streptomyces sp. SM01 isolated from Indian soil produces a novel antibiotic picolinamycin effective against multi drug resistant bacterial strains. Sci Rep 10:10092. https ://doi.org/10.1038/s4159 8-020-66984 -w

15. Minnikin DE, O'Donnell AG, Goodfellow M, Alderson G, Athalye M, Schaal K, Parlett JH (1984) An integrated procedure for the extraction of bacterial isoprenoid quinones and polar lipids. $J$ Microbiol Methods 2:233-241

16. Saitou N, Nei M (1987) The neighbor-joining method: a new method for reconstructing phylogenetic trees. Mol Bio Evol 4:406-425

17. Sasser M (1990) Identification of bacteria by gas chromatography of cellular fatty acids. Technical note 101.Newark: Microbial ID

18. Shirling EB, Gottlieb D (1966) Methods for characterization of Streptomyces species. Int J Syst Bacteriol 16:313-340

19. Staneck JL, Roberts GD (1974) Simplified approach to identification of aerobic actinomycetes by thin-layer chromatography. Appl Microbiol 28:226-231

20. Tang SK, Wang Y, Chen Y, Lou K, Cao LL, Xu LH, Li WJ (2009) Zhihengliuella alba sp. nov., and emended description of the genus Zhihengliuella. Int J Syst Evol Microbiol 59:2025-2031

21. Waksman SA (1967) The Actinomycetes. a Summary of Current Knowledge. New York: Ronald Press

22. Waksman SA, Henrici AT (1943) The nomenclature and classification of the actinomycetes. J Bacteriol 46:337-341

23. Wang C, Xu XX, Qu Z, Wang HL, Lin HP, Xie QY, Ruan JS, Hong K (2011) Micromonospora rhizosphaerae sp. nov., isolated from mangrove rhizosphere soil. Int J Syst Evol Microbiol 61:320324 
24. Williams ST, Davies FL (1967) Use of a scanning electron microscope for the examination of actinomycetes. J Gen Microbiol 48:171-177

25. Williams ST, Goodfellow M, Alderson G (1989) Genus Streptomyces Waksman and Henrici 1943, 339AL. In: Bergey's manual of systematic bacteriology pp 2452-2492

26. Xu P, Li W, Tang S, Zhang Y, Chen G, Chen H, Xu L, Jiang C (2005). Naxibacter alkalitolerans gen.nov., $s p$. nov., a novel member of the family Oxalobacteraceae isolated from China. Int J Syst Evol Microbiol 2005;55:1149-1153

27. Yokota A, Tamura T, Hasegawa T, Huang LH (1993) Catenuloplanes japonicus gen. nov., sp. nov., nom. rev., a new genus of the order actinomycetales. Int J Syst Bacteriol 43:805-812

28. Yoon SH, Ha SM, Kwon S, Lim J, Kim Y, Seo H, Chun J (2017) Introducing EzBioCloud: a taxonomically united database of $16 \mathrm{~S}$ rRNA and whole genome assemblies. Int J Syst Evol Microbiol 67:1613-21

\section{Figures}




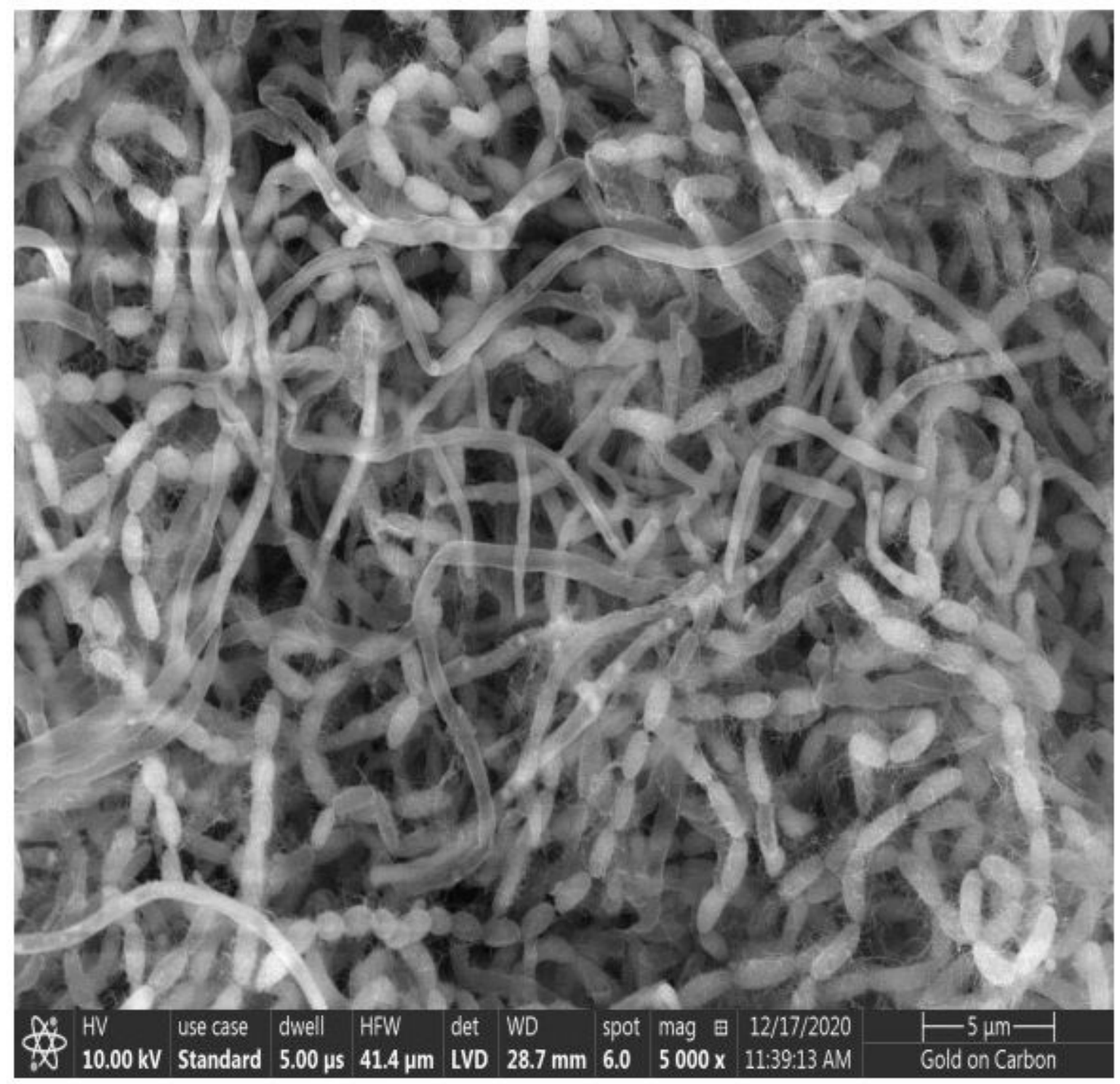

\section{Figure 1}

Scanning electron microscopy image of strain TRM75549T grown on Gauze's No. 1 agar at $30{ }^{\circ} \mathrm{C}$ for 7 days. Bars, $5 \mu \mathrm{m}$. 


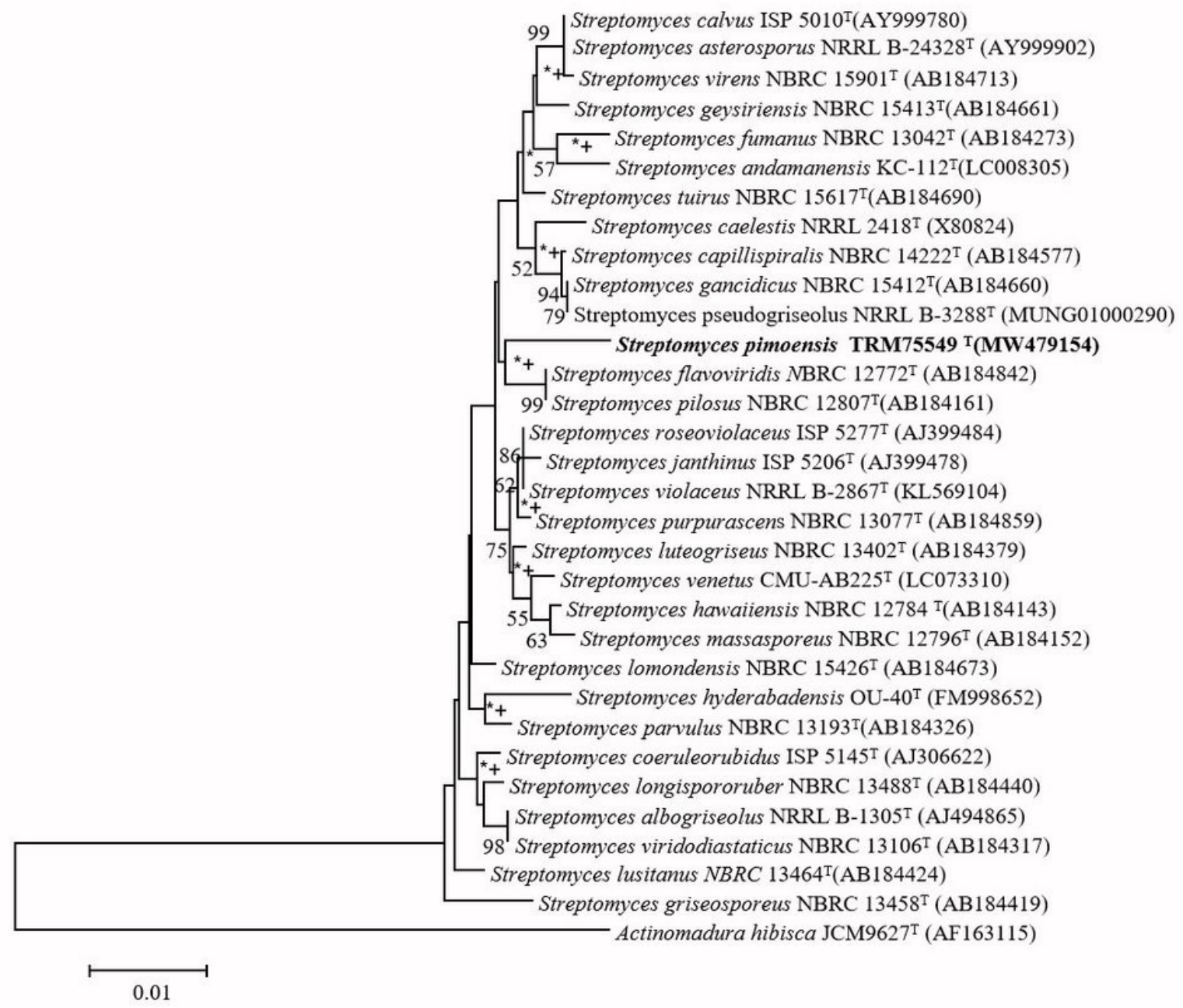

\section{Figure 2}

Neighbour-joining unrooted tree based on 16S rRNA gene sequences, illustrating the positions of strain TRM75549Tand related taxa. *, Branches that were also found using the maximum-parsimony method; +, branches that were also found using the maximum-likelihood method; ${ }^{*}+$, Branches that were found using all three methods. Numbers at nodes are percentage bootstrap values based on 1000 resampled datasets; only values above $50 \%$ are indicated. Bar, 0.01 substitutions per nucleotide position. 


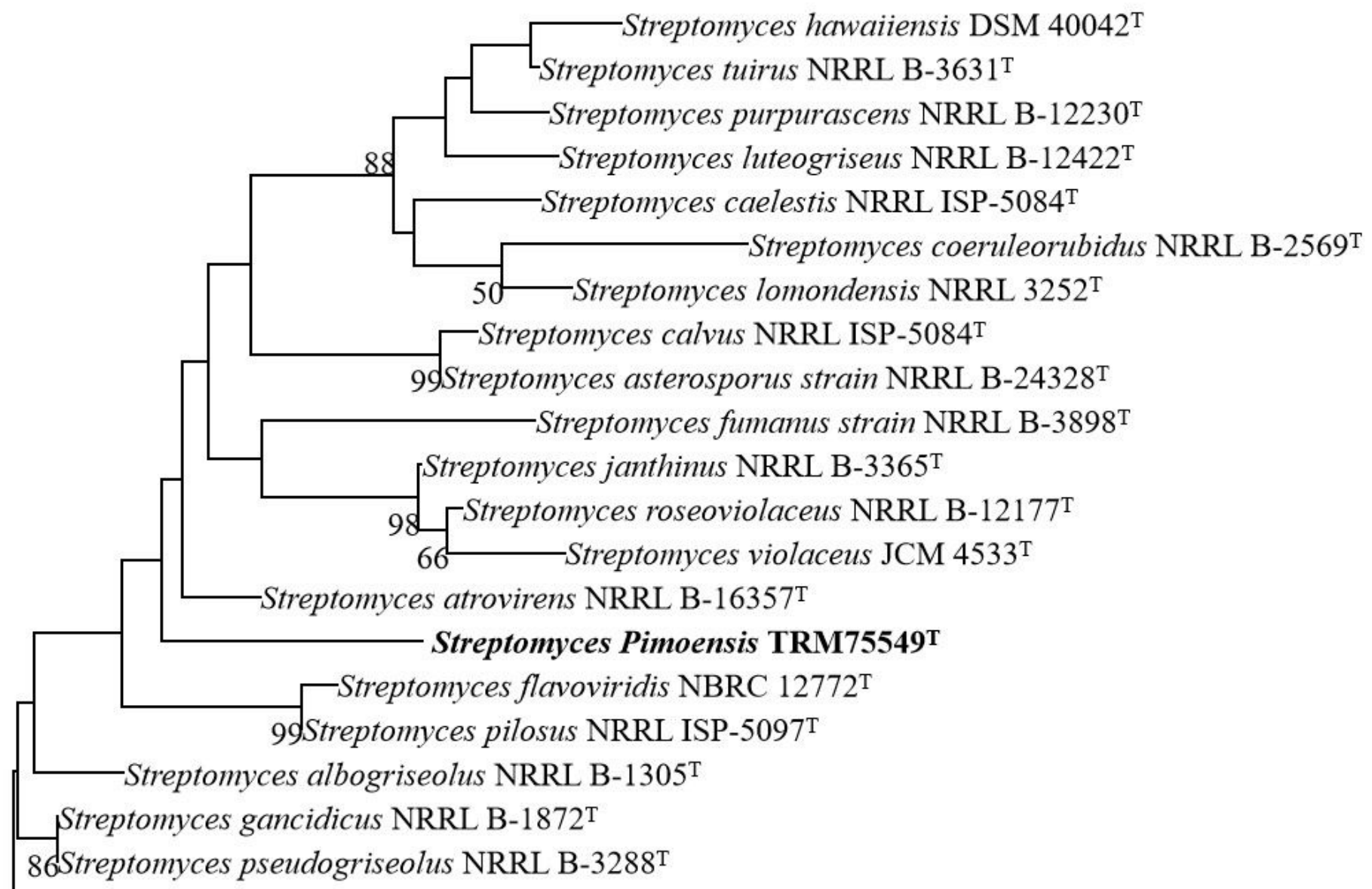
Streptomyces viridodiastaticus NRRL B-5622 ${ }^{\mathrm{T}}$

0.05

Figure 3

Neighbour-joining unrooted tree based on concatenated partial sequences of five housekeeping genes (atpD, gyrB, recA, rpoB and trpB) showing the position of strain TRM75549Tamongst its phylogenetic neighbours. Only bootstrap values above 50\% (percentages of 1000 replications) are indicated. Bar, 0.05 substitutions per nucleotide position.

\section{Supplementary Files}

This is a list of supplementary files associated with this preprint. Click to download.

- Supplementarydocuments.docx 